Estimating Subjective Quality of Life in Urban Seniors in Chile

Germán Lobos, Berta Schnettler, Klaus G. Grunert, Carmen Lapo, Rodrigo Saens, and Cristian Adasme-Berríos 
Germán Lobos, Berta Schnettler, Klaus G. Grunert, Carmen Lapo, Rodrigo Saens, and Cristian Adasme-Berrios

\section{Estimating Subjective Quality of Life in Urban Seniors in Chile}

Abstract: In recent years, measurement of quality of life has received increased attention. We use the satisfaction with life and subjective happiness scales in older adults living in urban areas in the Maule Region, Chile; generalized linear models are used ( $n=396)$. We find that (1) gender is linked to satisfaction with life, (2) satisfaction with one's own economic situation have significant effects on satisfaction with life and happiness, and (3) bealth, family and satisfaction with food are the most important predictors of both satisfaction with life and happiness.

Keywords: Satisfaction, happiness, urban areas, family, food. JEL Classification: A14, C21, D78.

\section{Estimando calidad de vida subjetiva en adultos mayores urbanos en Chile}

Resumen: En los últimos años, la medición de la calidad de vida ha recibido una creciente atención. Se utilizan las escalas de satisfacción con la vida y de felicidad subjetiva en adultos mayores residentes en áreas urbanas de la Región del Maule, Chile; se estiman modelos lineales generalizados $(n=396)$. Encontramos que (1) el género está ligado a la satisfacción con la vida, (2) la satisfacción con la propia situación económica tiene efectos significativos sobre la satisfacción con la vida y la felicidad, y (3) la salud, la familia y la satisfacción con la comida son los predictores más importantes tanto de la satisfacción con la vida como de la felicidad.

Palabras clave: Satisfacción, felicidad, áreas urbanas, familia, alimentación. 
Estimation de la qualité de vie subjective des personnes âgées urbaines au Chile Résumé: Ces dernières années, la mesure de la qualité de vie a rẹcu une attention croissante. Les échelles de satisfaction de vie et de bonheur subjectif sont utilisées chez les personnes âgées vivant dans les zones urbaines de la région de Maule, au Chili ; des modèles linéaires généralisés sont estimés $(n=396)$. Nous avons constaté que (1) le sexe est lié à la satisfaction de vivre, (2) la satisfaction de sa propre situation économique a des effets significatifs sur la satisfaction de la vie et le bonheur, et (3) la santé, la famille et la satisfaction avec la nourriture sont les prédicteurs les plus importants de la satisfaction de vie et du bonheur.

Mots clés: Satisfaction, bonheur, zones urbaines, famille, nourriture.

Cómo citar / How to cite this item:

Lobos-Andrade, G., Schnettler, B., Grunert, K. G., Lapo, C., Saens, R., \& AdasmeBerríos, C. (2021). Estimating Subjective Quality of Life in Urban Seniors in Chile. Lecturas de Economía, 95, 199-230.

https://doi.org/10.17533/udea.le.n95a342424 


\title{
Estimating Subjective Quality of Life in Urban Seniors in Chile
}

\author{
Germán Lobos $\oplus^{\mathrm{a}}$, Berta Schnettler $\oplus^{\mathrm{b}}$, Klaus G. Grunert $\oplus^{\mathrm{c}}$ Carmen \\ Lapo $\oplus^{\mathrm{d}}$, Rodrigo Saens $\odot^{\mathrm{e}}$, and Cristian Adasme-Berríos $\oplus^{\mathrm{f}}$
}

-Introduction. -I. Literature review. -II. Data and Methods. -III. Results. -IV. Discussion and Conclusions. -Declarations. -References

Original manuscript received on 12 June 2020; final version accepted on 10 February 2021

\section{Introduction}

The question 'what is the quality of life (QOL) in seniors?' has gained academic relevance as the population ages. In Latin America, the number of people over 60 years of age is expected to increase from 82.7 million in 2020 to 115.2 million by 2030 . This age group will then comprise $16.6 \%$ of the total population, while in Chile the population over 60 will be $23 \%$ of the total population (ECLAC, 2019). Researchers and policymakers generally agree that demographic changes and an aging population will put financial pressure on pensions and healthcare systems the world over. Increasingly, the global consensus is that we should not only be interested in living longer lives but we should also be concerned about the meaning of QOL for seniors.

a Germán Lobos: Professor at Faculty of Business and Economics, Universidad de Talca, Chile, and Visiting Professor at the Catholic University of Santiago de Guayaquil in Ecuador.

E-mail: globos@utalca.cl https://orcid.org/0000-0002-6155-4870

b Berta Schnettler: Professor at Universidad de La Frontera, Temuco, Chile, and Visiting Professor at the Catholic University of Santiago de Guayaquil in Ecuador.

E-mail: berta.schnettler@ufrontera.cl https://orcid.org/0000-0002-4438-3379

c Klaus G. Grunert: Professor at Aarhus University, Denmark. E-mail: klg@asb.dk https://orcid.org/0000-0001-8482-184X

d Carmen Lapo: Professor at Universidad Católica de Santiago de Guayaquil, Ecuador.

E-mail: maria.lapo@cu.ucsg.edu.ec https://orcid.org/0000-0002-1509-7242

e Rodrigo Saens: Professor at Faculty of Business and Economics, Universidad de Talca, Chile. E-mail: rsaens@utalca.cl https://orcid.org/0000-0002-8584-5445

f Cristian Adasme-Berrios: Professor at Facultad de Ciencias Sociales y Económicas, Universidad Católica del Maule, Chile. E-mail: cadasme@ucm.cl

https://orcid.org/0000-0003-1466-6420 
This leads to the following research question: What are the main variables related to subjective QOL in seniors? Several types of econometric models have been used in the literature to identify these variables and determine their sign and statistical significance. However, for the research problem posed in this study, generalized linear models (GLM) (Nelder \& Wedderburn, 1972) were used. An extension of the classic linear model, GLM use non-normal distributions of the errors and non-constant variances. The main findings of this study show that subjective QOL is related to health-related variables, family relations, socioeconomic factors and different elements of food-related life in urban seniors in seniors' centers in Central Chile.

Two aspects considered in this study have not been explored in previous research. First, given that tangible and intangible factors have different patterns in developed and developing countries, most of these previous studies on QOL refer to seniors from developed countries. Second, most of the literature on QOL in seniors has not provided empirical evidence about the relationship between QOL and satisfaction with food-related life as a hedonic dimension of the pleasure of food consumption, but rather only as a nutritional and physical health dimension. As Grunert et al. (2007) says, all experiences and circumstances in relation to buying, preparing and eating food are significant parts of life, but they have received little attention in the literature on QOL.

Thus, the main aim of this research is to identify the determinants of subjective QOL in seniors living in urban areas of a developing country like Chile. Also, this study seeks to contribute with scientific evidence about the role of satisfaction with food-related life in QOL. Finally, we expect to provide insights for policymakers to improve their perceptions and understanding of Chilean seniors living in urban areas.

An important limitation of this study is related to sample representativeness. The people interviewed were seniors living independently in their houses, noninstitutionalized and registered in a seniors' center. Therefore, the sample excludes those independent seniors who live in their own houses but are not registered in a seniors' center. A second limitation is that, due to the crosssectional nature of the data, the results do not permit causal inferences, only relationships between variables. 
We assume that subjective QOL and subjective well-being (SWB) are similar concepts. However, in this study we only use the term 'subjective QOL'. As Cella (1994) indicates, subjectivity refers to the fact that subjective QOL can only be understood from the person's perspective. QOL includes two main components (Schimmack et al. 2008): satisfaction with life (or cognitive well-being) and subjective happiness (or affective well-being). Therefore, although life satisfaction and subjective happiness are interrelated, they are not exactly the same (Gray et al. 2008). We measure life satisfaction using the satisfaction with life scale (SWLS) developed by Diener et al. (1985). Subjective happiness is assessed using the subjective happiness scale (SHS) developed by Lyubomirsky and Lepper (1999).

The article has four sections. Section I contains a literature review of the main variables related to QOL in seniors and the relations between subjective QOL, and a set of variables derived from the literature investigated in this study are indicated explicitly. Section II presents the design and sampling, participants, questionnaire application procedure, scales used and sociodemographic variables consulted as well as the statistical analysis, including descriptive statistics, correlations and the regression model used. Section III presents the results, structured in four parts: a confirmatory factor analysis, descriptive statistics, correlations among study variables and the predictions of the econometric model generated. Finally, section IV provides the discussion and conclusions, including the main implications from a public policy point of view.

\section{Literature review}

QOL in older ages is different from the general population (Netuveli \& Blane, 2008): as the years pass, QOL is affected by the changes that occur during the aging process (De Souza et al., 2018; Fisken et al., 2015). Based on a review of selected literature, Netuveli \& Blane (2008) concluded that most seniors evaluate their QOL positively on the basis of social contacts, dependency, health, material circumstances and social comparisons. However, two major factors to be considered with regard to QOL in old age are dementia and depression (Netuveli \& Blane, 2008). Several empirical 
studies show that QOL does not decrease with old age, although in old age there is an increasing risk of limitations or losses in health and competence, social networks and financial means (Pinquart \& Sörensen, 2000). Thus, maintaining high levels of QOL is considered a key aspect of successful aging.

At international level there is abundant literature that discusses the relationship between QOL in seniors and a set of tangible factors such as income, education, financial resources and/or working situation (Gray et al., 2008; Schnettler et al., 2014; Xavier et al., 2003), a range of psychosocial and health-related variables in men and women (Berg et al., 2006; Schnettler et al., 2014), change in functional ability in the oldest elderly population (Enkvist et al., 2012; Gray et al., 2008; Smith et al., 2002), social networks or social support (Berg et at., 2006; Gow et al., 2007; Gray et al., 2008; Tomás et al., 2014), self-reported altruistic activity and social capital (Theurer \& Wister, 2010), family situation (Silverstein et al., 2006), household composition, availability of neighbors and the role of children (Li et al., 2013; Lou, 2010; Moor et al., 2013; Yunong, 2012), and cross-cultural difference in predictors of life satisfaction between poorer and wealthy nations (Oishi et al., 2009).

According to the socio-environmental theory of aging developed by Gubrium (1973), seniors' life satisfaction is shaped by the interaction between individuals and their environments. The effects of these environments on seniors vary depending on family, health, financial status and social support. The results of Berg et al. (2006), Schnettler et al. (2014), Li et al. (2013), Moor et al. (2013), Tomás et al. (2014) and Yunong (2012) show that when controlling for socio-demographic variables, perceived health status, family relations and social support are important predictors of seniors' life satisfaction.

Some evidence indicates that life satisfaction varies across cultures. Diener et al. (1995), for example, show that there is a relationship between a society's economic development and its average level of subjective wellbeing. Oishi et al. (2009) conclude that financial satisfaction is more strongly associated with life satisfaction in developing countries, whereas home life satisfaction is more strongly related to life satisfaction in developed ones.

Perceived health is defined as the individual's perception of his or her health status. The results of Smith et al. (2002) and Enkvist et al. (2012) 
show that perceived health is an important predictor for quality of life of seniors. In Germany, Steverink et al. (2001) document a negative relationship between subjective health status and subjective well-being in later life. A similar relationship is presented in a Swedish study of about 300 people over the age of 80 by Berg et al. (2006). Li et al (2013) and Silverstein et al. (2006) conclude that seniors with perceived poorer health are more likely to experience lower levels of life satisfaction. Pinquart and Sörensen (2000) indicate that perceived poor health could affect seniors' sense of selfsufficiency and thus limit their involvement in their social support networks. In terms of the relationship between happiness and health status, some studies document a consistent relationship between poor health status and unhappiness in seniors (Okun et al., 1984; Lubin et al., 1988; Agner et al., 2013 and Chyi \& Mao, 2012). Other studies, however, find that when other factors are considered, perceived health status has little effect on happiness levels (Diener et al., 1995). For example, Russell \& Wells (1994) show that in seniors health status is not a significant predictor of happiness when family satisfaction and relationships with children are assessed. Likewise, Lyubomirsky et al. (2005) finds that perceived health is not a significant predictor of happiness after other variables are controlled.

There is also a growing body of literature examining the impact of family situation on life satisfaction in seniors. According to Li et al. (2013), Moor et al. (2013) and Yunong (2012), family members who offer emotional and financial support to their older relatives show how important family resources are to seniors' QOL. The results of Li et al. (2013) indicate that rural seniors in China who receive assistance from children are more likely to be satisfied with their lives. Moor et al. (2013) show that financial situation does not moderate the relationship between family support and life satisfaction.

Berg et al. (2006), Gow et al. (2007), Lou (2010), Theurer \& Wister (2010) and Tomás et al. (2014) examine the relation between social support and life satisfaction in seniors. The general social and emotional support from neighbors and friends are identified by Lou (2010) and Tomás et al. (2014) as factors contributing significantly to life satisfaction. Gow et al. (2007) document that social support explains $23 \%$ of life satisfaction variance in a multiple regression model, and Berg et al. (2006) show that quality of 
social network explains between $20 \%$ and $11 \%$ of life satisfaction variance, for women and men, respectively.

Several studies, such as those by Ferrer-i-Carbonell (2005) and Hsieh (2011), have shown a positive correlation between subjective well-being, an individual's income and an individual's perception of income. An individual's perception of income is dependent on their own income in relation to the past as well as to other people's income (George, 1992; Hsieh 2011; Layard 2005). Although most authors also agree on the significant influence of household income on happiness, Hsieh (2011) shows that after controlling for major socio-demographic variables, there is no evidence of a significant relationship between income and happiness for seniors. The results of Selim (2008) and Shams (2014) show the inexistence of significant differences in subjective happiness between senior men and senior women.

There is little evidence about the relation between satisfaction with food and the impact of these variables on QOL indicators (Grunert et al., 2007; Dean et al., 2008; Schnettler et al., 2014). Eating in pleasant surroundings clearly reflects the contribution of foods to hedonic well-being and social construction, as Kniazeva and Venkatesh (2007), and Schnettler et al. (2014) have suggested. According to Lobos et al. (2017), in future studies, the satisfaction with food may serve as a useful dependent variable to analyze how other objective indicators may be associated with that variable. Beyond food consumption as a fundamental aspect of the satisfaction of energy and nutrients needs, in this study we assessed the relation between QOL and a scale of satisfaction with food in terms of the hedonic pleasure associated with its consumption.

\section{Data and Methods}

\section{A. Design and sampling}

Two-stage sampling, stratified by clusters with incidental (casual) subsamples and (snowball) networks within the cluster were applied. Within each area the affixation is performed per cluster, also in proportion to the size of the sampled population. Seniors' centers were selected within each stratum by 
simple random sampling. The expected maximum absolute error level of the questionnaire results was $\pm 5 \%$ for a confidence level of $95 \%$. In this study independent seniors were interviewed, non-institutionalized and registered in a seniors' center. A seniors' center is a non-institutionalized center listed in the Chilean National Register of Social Organizations for seniors as part of the National Service for Senior Citizens (SENAMA). Seniors' centers are daily centers of formal groups of elderly people who meet to take part in activities of common interest that promote positive aging. Inclusion criteria were individuals with no physical (functional) or mental (dementia) disabilities, registered in a seniors' center and living in urban areas. This is justified because $67 \%$ of the population of the Maule Region is urban.

\section{B. Participants}

The sample was composed of 396 seniors (between 60 and 92 years old, including both male and female participants) from 30 communes of the Maule Region in Central Chile, $30.1 \%$ are male and $51.2 \%$ live alone. Their age range is between 60 and 92 years old with an average age of 71.3 (SD = 6.5). In general, the participants' family are relatively small: $55 \%$ of their families are composed of $1-2$ members and $20.9 \%$ of $3-4$ members. In $65.7 \%$ there are no children living in the participants' homes while in $4 \%$ of their homes there are children under 5 years old. Most of the seniors interviewed completed primary or secondary education $(76.7 \%)$.

\section{Procedure}

The Ethics Committee of the Universidad de Talca approved the study protocol. Participants were recruited through seniors' centers to answer the questionnaire either in the Center or in their residence. The participants signed informed consent statements before responding. The consent statements explained the strictly confidential treatment of the information obtained. The questionnaire was personally applied by trained interviewers during May 2013 and January 2014. Application of the questionnaire lasted 20-25 minutes. 
Lobos, Schnettler, Grunert, Lapo, Saens and Adasme-Berríos: Estimating Subjective Quality...

\section{Measures}

Two separate measures of subjective QOL are used as dependent variables: satisfaction with life and perceived happiness. Although satisfaction with life and happiness are two related constructs and have been grouped together by some researchers (Shams 2014; Veenhoven and Ehrhardt, 1995), they have also been considered separately (Selim 2008; Theurer \& Wister 2010; Wu et al. 2014). According to Theurer \& Wister (2010), it is useful to separate these concepts because their temporal references differ. Life satisfaction implies a review and judgment of the QOL one has experienced, whereas happiness is an assessment of life at the present time (Cummins, 1998). Sociodemographic information and other variables were entered into the models as control variables. The scales, socio-demographic information and other variables used in this study are presented as follows:

- The SWLS (Diener et al., 1985) is an instrument designed to measure global cognitive judgments of satisfaction with one's life and consists of five items grouped into a single dimension: 1. "In most ways my life is close to my ideal"; 2. "The conditions of my life are excellent"; 3. "I am satisfied with my life"; 4. "So far I have gotten the important things I want in life"; 5. "If I could live my life over, I would change almost nothing". In SWLS the respondents must indicate their degree of agreement with these statements using a 6-point Likert scale $(1=$ strongly disagree, $6=$ strongly agree). A SWLS scale with no midpoint (i.e., 6-point Likert scale) was used as previous testing of the instrument suggested a tendency by respondents to concentrate answers at the midpoint. In order to avoid the indecisive answers that tend to be concentrated at the midpoint, the scale that originally contained seven levels was changed to six. The calculation of the scale is obtained based on the sum score of all items where higher scores reflect greater satisfaction with life. In this study, the SWLS scale presented adequate levels of internal consistency (Cronbach's $\alpha=0.87$ ).

- The SHS developed by Lyubomirsky \& Lepper (1999) consists of four items that must be answered on a Likert-type scale of 1-7 points. First, "In general, I consider myself: $1=$ not a very happy person, $7=$ a very 
happy person. Second, "Compared with most of my peers, I consider myself: 1 = less happy, 7 = happier. Third, "Some people are generally very happy. They enjoy life regardless of what is going on, getting the most out of everything. To what extent does this characterization describe you?: $1=$ not at all, $7=$ a great deal. Fourth, "Some people are generally not very happy. Although they are not depressed, they never seem as happy as they might be. To what extent does this characterization describe you?: $1=$ not at all, $7=$ a great deal. Scores are totaled for the four items, and range from 4 to 28 . The calculation of the scale is obtained based on the average score of all items where higher scores reflect greater happiness. The SHS scale presented adequate levels of internal consistency (Cronbach's $\alpha=0.80)$.

- In order to measure perceived health status, we used the Health-Related Quality of Life Index (HRQoL) developed by Hennessy et al. (1994). The HRQoL consists of four items of healthy day measures. The first (HRQOL1) explores self-perceived overall health based on a personal assessment of current health or disease resistance. Self-perception of health is measured by the question: "How would you say your health is in general?" with a total score from $1=$ very poor to $5=$ excellent. The second item (HRQOL2) refers to the physical health state during the past 30 days. The third item (HRQOL3) explores the status of recent mental health. The fourth item (HRQOL4) refers to limitations for common activities during the past 30 days (called common activities). As Hennessy et al. (1994) suggested, to obtain the number of days with physical or mental problems in the last month, we added HRQOL2 and HRQOL3, with a maximum limit of 30 days in order to obtain the 'unhealthy days' index. The 'unhealthy days' index has been used in previous studies (Lobos et al., 2019; Lobos et al., 2016; Schnettler et al., 2014); in this study it was used as an independent variable in both models. In addition, we used HRQOL1 on its own to describe selfperceived overall health. In this study the Cronbach's $\alpha$ of three of the four items was 0.67 .

- The importance placed on family as a source of individual subjective well-being is measured using the family values questionnaire adapted 
Lobos, Schnettler, Grunert, Lapo, Saens and Adasme-Berríos: Estimating Subjective Quality...

by Burroughs \& Rindfleisch (2002) from Faver (1981) and Glezer (1984). According to Burroughs \& Rindfleisch (2002), this family importance scale (FIS) is a five-item scale that focuses on the importance respondents place on family relations and has solid face validity and acceptable reliability. The respondent had to answer how much they agree with each of the six items on a six-point Likert-type scale scoring from 1 (strongly disagree) to 6 (strongly agree). A higher score on the FIS means that the person assigns greater importance to family. In this study, the FIS scale presented adequate levels of internal consistency (Cronbach's $\alpha=0.78$ ).

- As a measure of how satisfied seniors are with food in their life, we used the Satisfaction with Food-Related Life (SWFL) proposed and tested by Grunert et al. (2007) in eight European countries. This measure of satisfaction with food-related life consists of 5 items grouped in a single dimension, rated on a 6-level Likert-type scale scoring from 1 (strongly disagree) to 6 (strongly agree). The calculation of the SWFL is obtained based on the total score of all the items, with higher scores reflecting greater satisfaction with food-related life. The SWFL scale presented adequate levels of internal consistency (Cronbach's $\alpha=0.87$ ).

- We also asked the respondents about their 'satisfaction with the economic situation' (SWES), which was adapted from the scale proposed by Loewe et al. (2014). The one-item, six-point Likert-type scale scores from 1 (extremely dissatisfied) to 6 (extremely satisfied). In this study, we recoded this scale into three categories: 1 (dissatisfied), 2 (slightly satisfied) and 3 (satisfied).

The socio-demographic information included was age (in years), gender $(1=$ male, 2 = female $)$, living circumstances, $(1=$ living alone, $2=$ living with a partner, i.e., any companion they live with $)$, education $(1=$ no education, $2=$ primary or secondary education, 3 = technical training or university education), number of children living at home, and quantity of domestic household goods (QGoods). We used the technique proposed by Adimark (2004) to classify the respondents according to their socioeconomic level by crossing the variables education and QGoods. Thus, socioeconomic level $(1=A B C 1$ is high and upper-middle, $2=C 2$ is middle-middle, $3=C 3$ is middle-low, $4=D$ is low, $5=E$ is very low). 


\section{E. Data collection and statistical analysis}

The interviewers explained to the respondents the objectives of the survey and the strictly confidential treatment of the information obtained. The respondents were continually asked if they were prepared to answer the questionnaire. The participants signed informed consent statements before answering the questionnaire. The execution of the study was approved by the Ethics Committee of the Universidad de Talca. The results were analyzed using the Statistical Package for Social Sciences (version 22, SPSS, IBM Corp., Armonk, NY, 2014) and MPlus 8.

A descriptive analysis was conducted to compute mean scores with standard deviation (SD) for quantitative variables and frequencies $(\%)$ for qualitative variables. A confirmatory factor analysis (CFA) was performed to identify the measurement model. The goodness of fit of the CFA model was assessed through $\chi^{2} / d f$, root mean square error of approximation (RMSEA), comparative fit index (CFI) and the Tucker-Lewis index (TLI). In addition, we determined the convergent validity and the reliability of the constructs. To estimate the effect size (Cohen's d) when testing for gender differences for the SWLS and the SHS, the effect size calculators for the $t$ test from Social Science Statistics (2020) were used. As a correlation measure between quantitative variables the Pearson correlation coefficient was used, Spearman's Rho for correlation between ordinal variables and Kendall's Tau$\mathrm{b}$ for correlation between quantitative and ordinal variables. We used the GLM (Nelder \& Wedderburn, 1972) for the estimations.

\section{Results}

\section{A. Confirmatory factor analysis}

In this study a CFA was carried out for all the constructs (Satisfaction with life, subjective happiness, Health-related Quality of Life, family importance and Satisfaction with Food-related Life). The results of this procedure led to the conclusion that this analysis was suitable. Table 1 summarizes CFA results and shows parameters used to test the robustness of the constructs. In relation to the reliability of factor loading, most were above 0.5 , and the $t$-values of 
each item were significantly associated with specified constructs $(p<0.001)$ (Bagozzi \& Phillips, 1991). The internal consistency of the model was assessed through the composite reliability test (CR), in which most of the constructs were close to or above 0.7 , and the internal consistency reliability measured by Cronbach's $\alpha$ (CA) (ideally above 0.7 ) and the average variances extracted (AVE) were close to or above 0.5 . Since correlations among constructs did not exceed 0.85 , discriminant validity was obtained. Therefore, the scales used in the study presented moderate to high reliability and validity. Consequently, the internal validity of the measurement model was adequate.

\section{B. Descriptive statistics}

The sample characteristics are presented in Table 2. The mean score of the quantity of domestic household goods was $7(\mathrm{SD}=2)$. The mean score of the unhealthy days was $6.2(\mathrm{SD}=9.7)$. The vast majority of respondents belong to the less affluent sectors of society. In fact, the socioeconomic classification indicates that $38.7 \%$ belongs to the $\mathrm{D}$ stratum (lower), $32.4 \%$ to C3 (middle-lower) and 15.4\% to C2 (middle-middle). In general, we observed a high satisfaction with the economic situation: $48.5 \%$ believes that their current economic situation is adequate and $30.9 \%$ believes it is more than adequate. It is noteworthy, therefore, that most of the sample has a low education level, belongs to the lower social classes, but also has a high relative satisfaction with their financial situation.

The mean (SD) satisfaction with life score was 21.7 (4.0) on a 6 to 30-point scale. Also, a male mean score of $20.4(\mathrm{SD}=4.0)$ and a female mean score of 22.2 ( $\mathrm{SD}=2.0)$ showed that the women's average score was significantly higher than the men's $(t=-4.315, p<0.01)$. For the satisfaction with life the effect size estimate was Cohen's $d=0.57$. The mean (SD) happiness score was 5.2 (1.1) on a 7-point scale. Also, a male mean score of 4.9 (SD $=1.0)$ and a female mean score of $5.3(\mathrm{SD}=1.0)$ showed that the women's average score was significantly higher than the men's $(t=-3.309, p<0.01)$. For happiness the effect size estimate was Cohen's $d=0.4$. The perceived health results indicated that $14.9 \%$ of the sample perceived very good overall health, $47.1 \%$ good overall health and $33.4 \%$ fair overall health. 
Table 1. Reliability and validity of the standardized confirmatory factor analysis (CFA)

\begin{tabular}{|c|c|c|c|c|c|}
\hline Variables & $\begin{array}{l}\text { Standardized } \\
\text { Loading }\end{array}$ & $t$-value & Cronbach's $\alpha$ & Composite Reliability & $\begin{array}{c}\text { Average Variance } \\
\text { Extracted }\end{array}$ \\
\hline \multicolumn{3}{|c|}{ Satisfaction with life scale (SWLS) } & 0.87 & 0.90 & 0.65 \\
\hline SWLS1 & 0.767 & 39.875 & & & \\
\hline SWLS2 & 0.893 & 69.606 & & & \\
\hline SWLS3 & 0.872 & 63.014 & & & \\
\hline SWLS4 & 0.771 & 36.004 & & & \\
\hline SWLS5 & 0.717 & 30.362 & & & \\
\hline \multicolumn{3}{|c|}{ Subjective happiness scale (SHS) } & 0.80 & 0.85 & 0.59 \\
\hline SHS1 & 0.911 & 41.963 & & & \\
\hline SHS2 & 0.838 & 34.589 & & & \\
\hline SHS3 & 0.768 & 27.768 & & & \\
\hline SHS4 & 0.500 & 13.496 & & & \\
\hline \multicolumn{3}{|c|}{ Health-related Quality of Life (HRQOL) } & 0.67 & 0.66 & 0.40 \\
\hline HRQOL2 & 0.550 & 10.137 & & & \\
\hline HRQOL3 & 0.707 & 10.758 & & & \\
\hline HRQOL4 & 0.625 & 10.764 & & & \\
\hline \multicolumn{3}{|c|}{ Family importance scale (FIS) } & 0.78 & 0.92 & 0.65 \\
\hline FIS1 & 0.727 & 16.692 & & & \\
\hline FIS2 & 0.727 & 16.692 & & & \\
\hline FIS3 & 0.854 & 52.081 & & & \\
\hline FIS4 & 0.747 & 35.182 & & & \\
\hline FIS5 & 0.926 & 73.696 & & & \\
\hline FIS6 & 0.852 & 54.321 & & & \\
\hline \multicolumn{3}{|c|}{ Satisfaction with Food-related Life (SWFL) } & 0.87 & 0.90 & 0.65 \\
\hline SWFL1 & 0.766 & 41.112 & & & \\
\hline SWFL2 & 0.895 & 71.112 & & & \\
\hline SWFL3 & 0.874 & 61.480 & & & \\
\hline SWFL4 & 0.771 & 36.099 & & & \\
\hline SWFL5 & 0.693 & 29.930 & & & \\
\hline \multirow[t]{3}{*}{ Measurement model } & & $\chi^{2} / d f=2.76$ & $\mathrm{p}=0.000$ & & \\
\hline & & & & $\mathrm{CFI}=0.975$ & $\mathrm{TLI}=0.970$ \\
\hline & & & & RMSEA $=0.066$ & \\
\hline
\end{tabular}

Note: CFI: Comparative fit index, TLI: Tucker-Lewis index, RMSEA: Root mean square error of approximation.

Source: own calculations. 
Lobos, Schnettler, Grunert, Lapo, Saens and Adasme-Berríos: Estimating Subjective Quality...

Table 2. Definitions and sample characteristics, older adults living in urban areas

\begin{tabular}{|c|c|c|c|}
\hline Variable & Definition & Mean or \% & SE \\
\hline Age & In years & 71.3 & 6.5 \\
\hline Male & Dummy variable $(1=$ male, $2=$ female $)$ & 30.1 & - \\
\hline Living alone & $\begin{array}{l}\text { Dummy variable }(1=\text { living alone, } 2=\text { living with a } \\
\text { partner, i.e., any companion they live with) }\end{array}$ & 51.2 & - \\
\hline \multirow[t]{4}{*}{ Education } & Education in three levels & & \\
\hline & $1=$ no education & 7.8 & - \\
\hline & $2=$ primary or secondary education & 76.7 & - \\
\hline & $3=$ technical training or university education & 15.4 & - \\
\hline Children & Children living at home. Number (range: 0-6) & 1.6 & 0.9 \\
\hline QGoodsa $^{\mathrm{a}}$ & Possession of domestic goods, number, range: $0-10$ ) & 7.0 & 2.0 \\
\hline \multirow[t]{4}{*}{ SWES } & $\begin{array}{l}\text { Satisfaction with the economic situation attainment in } \\
3 \text { levels }\end{array}$ & & \\
\hline & $1=$ dissatisfied & 20.6 & - \\
\hline & 2 = slightly satisfied & 48.5 & - \\
\hline & $3=$ satisfied & 31.0 & - \\
\hline Unhealthy days & Number (range: $0-30$ ) & 6.19 & 9.7 \\
\hline \multirow[t]{3}{*}{ SWLS } & Satisfaction with Life Scale. Number (range: 5-30) & 21.7 & 4.0 \\
\hline & $1=$ male & 20.4 & 4.0 \\
\hline & $2=$ female & 22.2 & 2.0 \\
\hline \multirow[t]{3}{*}{ SHS } & Subjective Happiness Scale. Number (range: $1-7$ ) & 5.2 & 1.1 \\
\hline & $1=$ male & 4.9 & 1.0 \\
\hline & $2=$ female & 5.3 & 1.0 \\
\hline FIS & Family Importance Scale, number (range: 6-36) & 26.0 & 5.6 \\
\hline SWFL & $\begin{array}{l}\text { Satisfaction with Food-related Life scale, number (range: } \\
5-30 \text { ) }\end{array}$ & 22.6 & 4.1 \\
\hline
\end{tabular}

Note: SE: standard error. ${ }^{a}$ Including shower, color TV, refrigerator, washing machine, kettles, microwaves, automobile, cable TV, PC and Internet.

Source: own calculations. 
Table 3. Correlations among study variables ${ }^{a, b}$

\begin{tabular}{lccccccccc}
\hline Variable & -1 & -2 & -3 & -4 & -5 & -6 & -7 & -8 & -9 \\
\hline (1) Age & 1 & -0.09 & $-0.21^{* * *}$ & -0.04 & -0.07 & 0.06 & 0.03 & 0.01 & -0.01 \\
(2) Female & 1 & -0.09 & $0.21^{* * *}$ & $0.17^{* * *}$ & $0.21^{* * *}$ & $0.13^{* * *}$ & $0.20^{* * *}$ & $0.18^{* * *}$ \\
(3) living with a partner, & & 1 & $0.12^{* *}$ & -0.09 & 0.04 & 0.07 & -0.00 & $0.11^{* * *}$ \\
i.e., any companion they \\
live with
\end{tabular}

Note: ${ }^{a}$ Pearson correlation coefficient for quantitative variables, Spearman's Rho for ordinal variables and Kendall's Tau-b for quantitative and ordinal variables; ${ }^{b}$ Significant variables at $* p<0.1$, at $* p<0.05$, at $* * * p<0.01$ based on bilateral test.

Source: own calculations.

\section{Correlations among study variables}

Bivariate correlation coefficients were assessed to understand underlying associations among study variables (Table 3). The Pearson bivariate correlation between satisfaction with life and subjective happiness was $0.57(p<0.01)$, between satisfaction with life and Satisfaction with Food-Related Life 0.62 $(p<0.01)$, and between subjective happiness and Satisfaction with Food-Related Life $0.42(p<0.01)$. Greater satisfaction with life was observed among the 'happiest' seniors. Satisfaction with life is also positively associated with satisfaction with the economic situation, family and food. Happiness is positively associated with satisfaction with the economic situation, family, food and healthy days. Based on Kendall's Tau-b $(T)$ we observed a statistically significant correlation between age and living alone $(T=-0.21, p<0.01)$. Based on Spearman's Rho ( Rho ) we noted a statistically significant correlation between satisfaction with the economic situation and female gender $(R h o=0.21, p<0.01)$, and living with 
a companion $(R h o=0.12, p<0.05)$. There was a statistically significant correlation between education and the most indicators of quality of life in old age. For example, between education and satisfaction with life $(T=0.1, p<0.05)$, Satisfaction with Food-Related Life $(T=0.09, p<0.05)$, and self-perceived overall health $(R h o=0.11, p<0.05)$. We also observed a statistically nonsignificant Pearson correlation between age and satisfaction with life $(\rho=0.09$, $p>0.1)$ and subjective happiness $(\rho=0.08, p>0.1)$.

\section{Generated generalized linear models}

We used GLM (Nelder and Wedderburn, 1972) to examine the relationship between QOL and different study variables. The results of the GLMs are presented in two steps in Table 4. In Step 1 the results shown are those for the null model that includes socio-demographic variables. In Step 2 the results shown are those corresponding to the full model (or saturated model), which adds the variables related to health, family and satisfaction with food to the null model.

The fit of the models is significant at the level of $p<0.01$ for the likelihood ratio $\chi^{2}$. Furthermore, the deviance of the saturated models was 0.44 for satisfaction with life and 0.26 for happiness. The signs of the coefficients show precisely the direction of the relationship of each independent variable with the satisfaction with life and happiness variables. We worked with a significance level of $10 \%(p<0.1), 5 \%(p<0.05)$ and $1 \%(p<0.01)$. The signs of the coefficients, in general, agree with the expectations.

The first step in the linear model of seniors' satisfaction with life revealed negative significant relationships for men, and less than adequate and adequate satisfaction with the economic situation. This implies that women and individuals with greater satisfaction with the economic situation are more satisfied with their life compared to men and individuals with less satisfaction with the economic situation. The linear model generated for happiness revealed negative significant relationships for less than adequate and adequate satisfaction with the economic situation. This also implies that those who have more satisfaction with the economic situation are happier than those who are less satisfied with the economic situation. Whether or not 
an elderly person is older or younger, male or female (only for the happiness model), lives alone or with a companion, is more or less educated, lives with or without children at home or has more or fewer domestic household goods seems to have no effect on their satisfaction with subjective quality of life.

Table 4. Regression coefficients from linear models

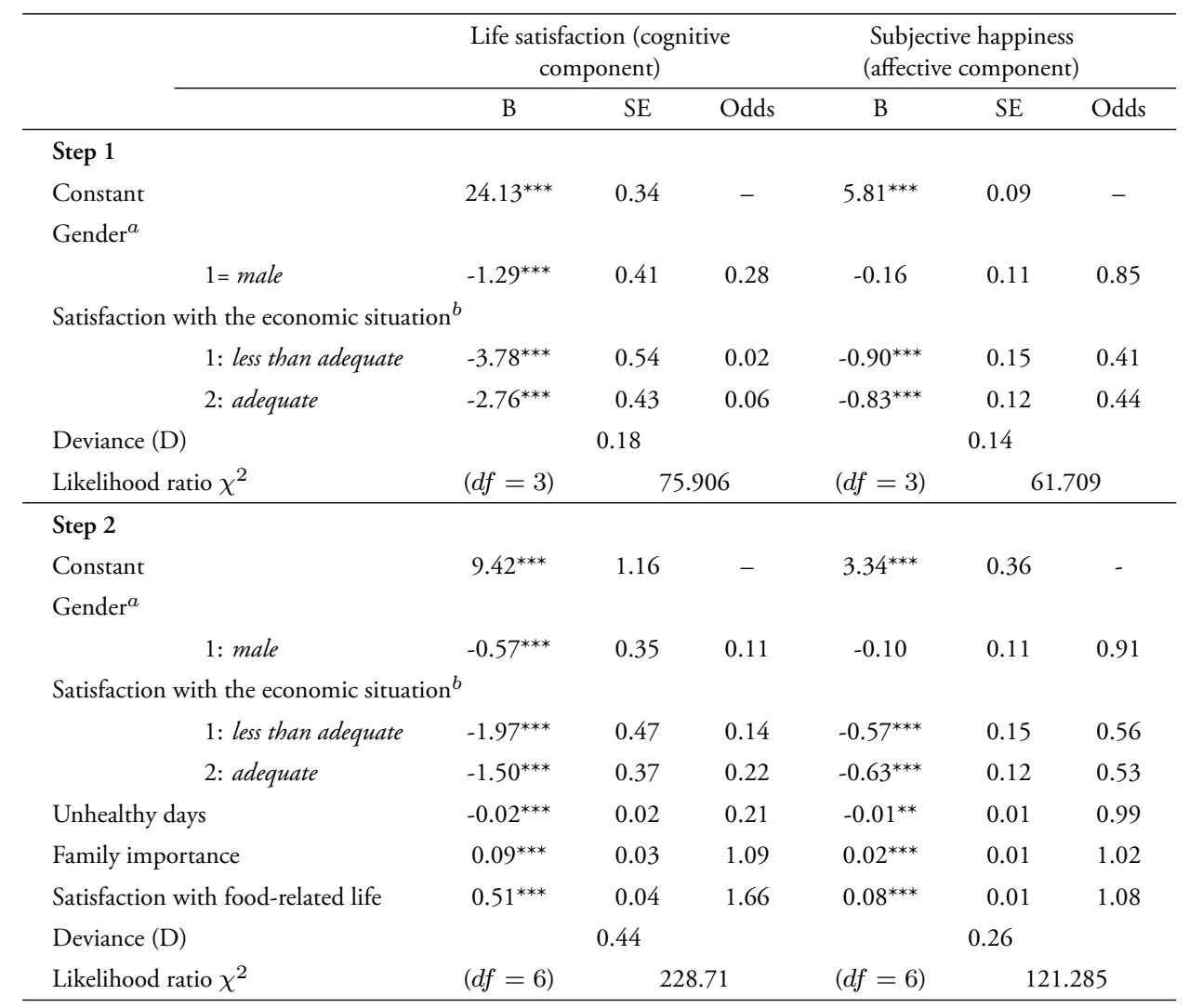

Note: B: Coefficient. SE: standard error. a ' $2=$ female' category omitted; b ' $3=$ more than adequate' category omitted. Significance levels: ${ }^{*} p<0.1,{ }^{*} p<0.05$, a ${ }^{* * *} p<0.01$. Deviance $=$

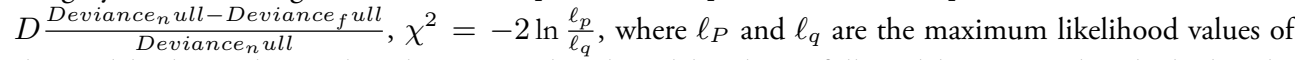
the models obtained. $p$ and $q$ when $p=$ reduced model and $q=$ full model, respectively. The higher the value of likelihood ratio, thus stronger against the null hypothesis, and therefore, the contribution of the variable incorporated at each step is significant.

Source: own calculations. 
In the second step, the linear model of satisfaction with life in terms of gender, satisfaction with the economic situation, unhealthy days, family importance and Satisfaction with Food-Related Life revealed negative significant relationships for men, less than adequate and adequate satisfaction with the economic situation, and unhealthy days, and positive significant relationships for family importance and Satisfaction with Food-Related Life. The linear model generated for happiness in terms of satisfaction with the economic situation, unhealthy days, family importance and Satisfaction with Food-Related Life revealed negative significant relationships for less than adequate and adequate satisfaction with the economic situation and unhealthy days, and positive significant relationships for family importance and Satisfaction with Food-Related Life.

The increase in explained variance for the linear models (change in $D$ ) from the first to second stage revealed it was significant $p<0.01$ for satisfaction with life $(\Delta D=26 \%)$ and happiness $(\Delta D=12 \%)$. This showed that in both satisfaction with life and happiness models the healthrelated variable (unhealthy days) and food and friends-related variables (family importance and food satisfaction) significantly increased the prediction of satisfaction with life and happiness.

\section{Discussion and Conclusions}

Using data from a questionnaire applied to 396 seniors in central Chile, in this paper we analyzed the effect of the set of tangible and intangible factors on subjective QOL. Given that the questionnaire was applied to non-institutionalized seniors registered in SENAMA, we recognize a sample selection bias, which means that the results cannot be extrapolated to the entire senior population in Chile. Hence, the individuals interviewed already have a positive attitude to life due to their participation in activities for seniors, such as workshops grouped in three areas: personal, social and community. In addition, seniors' centers are day centers where adults in the three first quintiles of vulnerability who present slight dependency, cognitive decline or slight depression can participate. They should preferably be resident in the commune where the center is located. 
We establish associative relations between subjective QOL and a group of variables linked to aspects such as socio-demographics, economic situation, health (unhealthy days), family importance and satisfaction with food consumption. In this study cognitive QOL (life satisfaction) was measured with SWLS, and affective QOL (subjective happiness) was measured with SHS.

Our results showed that life satisfaction is associated more significantly with gender, SWES, unhealthy days, family importance and SWFL, whereas subjective happiness is associated more significantly with SWES, unhealthy days, family importance and SWFL.

It is interesting to consider the relationship between QOL and SWES. Unlike the findings in the literature regarding financial capacity (Li et al. 2013; Loewe et al., 2014; Lou 2010) or household income (Hsieh 2011; Selim 2008; Shams 2014; Clark et al. 2008), in our study SWES is associated with both cognitive and affective QOL. We infer that urban seniors have a better QOL as they are more satisfied with their economic situation. This finding is consistent with the results of Horstmann et al. (2012), who report a high correlation between life satisfaction and satisfaction with income. We emphasize that the satisfaction with one's own economic situation is a variable that contributes to explaining the QOL, although in our results variables associated with income (i.e., socioeconomic level and expenditure on food consumption) were not statistically significant.

We find a positive and significant relationship between people's food satisfaction and QOL. This result is consistent with the findings of Dean et al. (2008), Grunert et al. (2007), Schnettler et al. (2012), Schnettler et al. (2013) and Schnettler et al. (2014). Daily basic needs like food can be an important source of life satisfaction for people, mainly because eating is not only a biological act, but also an act of subjective and social significance that binds individuals who need affection and recognition as part of their identity.

The findings of this study also provide evidence that unhealthy days are associated with QOL. These results are also consistent with some previous empirical findings (Horstmann et al. 2012; Li et al. 2013; Moor et al. 2013; Sok 2010; Tomas et al. 2014; Yunong 2012). As suggested by Angner et al. 
(2013), our results support the notion that the functional relationship between objective health status and subjective happiness must be understood in terms of approaches that incorporate additional psychological and social elements. The relationship between happiness and the number of unhealthy days can be explained by considering this variable a subjective indicator of health which contributes, as Angner et al. (2013) suggest, to disrupting seniors' daily functioning. This has implications for the affective component of well-being as well as other biological, psychological and social factors. Moreover, the statistical significance of the recent state of physical or mental health observed in our happiness model is in line with works by Ferrer-i-Carbonell \& Frijters (2004) and Veenhoven (2008). Beyond how health status is measured, the consequences of these findings on public health policy for the elderly are that the emphasis should be on prevention, by establishing policies to promote active and healthy aging and strengthening overall lifestyles that contribute to a healthier life for seniors.

Our results suggest that gender plays a significant role in the model produced for life satisfaction: male seniors are less satisfied with their lives than female seniors. However, gender does not play a significant role in the model generated for subjective happiness, which is consistent with findings from previous studies (Selim 2008; Shams 2014). These results differ from findings of some previous studies on seniors in European countries (Angelini et al. 2012; Moor et al. 2013) and Korea (Sok 2010). The discrepancy between our results and those of Angelini et al. (2012), Moor et al. (2013) and Sok (2010) could be because these studies describe seniors living in developed countries, where seniors not only have more and better social services, but are also embedded in places and pension systems where the income distribution is significantly more egalitarian.

The results in this paper indicate that the number of children at home is not an important factor related to seniors' quality of life. This result is consistent with those obtained by Lou (2010) and Li et al. (2013), but they differ from other results reported in the literature (for example, Selim 2008; Chyi \& Mao 2012; Shams 2014). We could propose one hypothesis to explain this situation: In Chile seniors do not necessarily need to have children living at home to feel more satisfied with life as they already frequently share moments with them. 
In this work, we also show that satisfaction with food achieves an important role as a factor related to subjective QOL in seniors. As the literature suggests, in this sense we postulate that the satisfaction with food is associated with hedonic pleasure (Hausman, 2005), celebrations and social interaction (Hargreaves et al., 2002) and the pleasure of enjoying the company of family and friends. This aspect of our work can contribute to the design of public policies associated with an elderly citizen's food, associating quality of life in old age with hedonic welfare in the consumption of food.

Finally, the results of this work confirm the importance of SWES, healthrelated variables, family importance and satisfaction with food as factors related to subjective QOL. These factors appear to be more significant than factors associated with money, such as income or socioeconomic status. It is important for policymakers to design public policies and social intervention strategies considering the perception of seniors with respect to the factors that influence their subjective QOL.

\section{Declarations}

Funding. This study was supported by the Interdisciplinary Excellence Research Program on Healthy Ageing (PIEI-ES), University of Talca, Chile (no grant number applicable). Conflicts of interest/Competing interests (include appropriate disclosures) The authors declare that they have no competing interests. Availability of data and material (data transparency) Please contact corresponding author for data requests. Code availability (software application or custom code) The software SPSS 22 was used for conducting the study or data analysis and the corresponding author has all the appropriate legal rights.

\section{References}

Adimark. (2009). Mapa socioeconómico de Chile: Nivel socioeconómico de los hogares del pais basado en datos del Censo. Investigación de Mercados y Opinión Pública. Santiago, Chile. https://es.slideshare.net/AngeloOr tega/MapaSocioeconomicodeChile. Accessed 30 December 2018. 
Lobos, Schnettler, Grunert, Lapo, Saens and Adasme-Berríos: Estimating Subjective Quality...

Angelini, V., Cavapozzi D., Corazzini, L., \& Paccagnella, O. (2012). Age, health and life satisfaction among older Europeans. Social Indicators Research 105, 293-308. https://doi.org/10.1007/s11205-011-9882-x

Angner, E., Ghandhi, J., Purvis, K. W., Amante, D., \& Allison, J. (2013). Daily functioning, health status, and happiness in older adults. Journal of Happiness Studies 14, 1563-1574. http://dx.doi.org/10.1007/s1090 2-012-9395-6

Bagozzi, R. P., Yi, Y., \& Phillips, L. W. (1991). Assessing construct validity in organizational research. Administrative Science Quarterly 36 (3), 421458. https://doi.org/10.2307/2393203

Berg, A.I., McClearn, G.E., Hassing, L.B., \& Johansson, B. (2006). What matters for life satisfaction in the oldest-old? Aging \& Mental Health 10 (3), 257-264. https://doi.org/10.1080/13607860500409435

Burroughs, J. E., \& Rindfleisch, A. P. (2002). Materialism and well-being: A conflicting values perspective. Journal of Consumer Research 29 (3), 348-370. https://doi.org/10.1086/344429

Cella, D.F. (1994). Quality of life: Concepts and definition. Journal of Pain and Symptom Management 9(3), 186-192. https://doi.org/10.1016/08 85-3924(94)90129-5

Chyi, H., \& Mao, S. (2012). The determinants of happiness of China's elderly population. Journal of Happiness Studies 13 (1), 167-185. https: //doi.org/10.1007/s10902-011-9256-8

Clark, A.E., Frijters, P., \& Schields, M.A. (2008). Relative income, happiness and utility: An explanation for the Easterlin paradox and other puzzles. Journal of Economic Literature, 46 (1), 95-144. http://dx.doi.org/10.12 $57 /$ jel.46.1.95

Cummins, R. A. (1998). The second approximation to an international standard for life satisfaction. Social Indicators Research 43 (3), 307-334. http://dx.doi.org/10.1023/A:1006831107052 
Dean, M., Grunert, K. G., Raats, M., Nielsen, N. A., Lumbers, M., \& The Food in Later Life Team. (2008). The impact of personal resources and their goal relevance on satisfaction with food-related life among the elderly. Appetite 50, (2-3), 308-315. https://doi.org/10.1016/j.appe t.2007.08.007

De Souza, L.N.N., De Carvalho, P.H.B., \& Ferreira, M.E.C. (2018). Quality of life and subjective well-being of physically active elderly people: a systematic review. Journal of Physical Education and Sport 18 (3), 16151623. https://doi.org/10.7752/jpes.2018.03237

Diener, E., Emmons, R. A., Larsen, R. J., \& Griffin, S. (1985). The satisfaction with life scale. Journal of Personality Assessment, 49 (1), 71 75. http://dx.doi.org/10.1207/s15327752jpa4901_13

Diener, E., Diener, M., \& Diener, C. (1995). Factors predicting the subjective well-being of nations. Journal of Personality and Social Psychology, 69 (5), 851-864. https://doi.org/10.1037/0022-3514.69.5.851

ECLAC. (2012). Population estimates and projections by sex and quinquennial age groups (Period 1950-2100). Economic Commission for Latin America and the Caribbean. Santiago, Chile. https://www.cepal.org/es /temas/proyecciones-demograficas/estimaciones-proyecciones-excel

Enkvist, Å., Ekström, H., \& Elmståhl, S. (2012). Associations between functional ability and life satisfaction in the oldest old: results from the longitudinal population study Good Aging in Skåne. Clinical Interventions in Aging 7, 313-320. https://doi.org/10.2147/CIA.S3 3610

Faver, C. A. (1981). Women, careers, and family: Generational and life-cycle effects on achievement orientations. Journal of Family Issues 20 (1), 91112. https://doi.org/10.1016/0001-8791(82)90064-1

Ferrer-i-Carbonell, A., \& Frijters, P. (2004). How important is methodology for the estimates of the determinants of happiness? The Economic Journal 114 (497), 641-659. https://doi.org/10.1111/j.1468-0297. 2004.00235.x 
Lobos, Schnettler, Grunert, Lapo, Saens and Adasme-Berríos: Estimating Subjective Quality...

Ferrer-i-Carbonell, A. (2005). Income and well-being: an empirical analysis of the comparison income effect. Journal of Public Economics 89, 5-6, 997-1019. https://doi.org/10.1016/j.jpubeco.2004.06.003

Fisken, A.L., Waters, D.L., Hing, W.A., Steele, M., \& Keogh, J.W. (2015). Comparative effects of 2 aqua exercise programs on physical function, balance, and perceived quality of life in older adults with osteoarthritis. Journal of Geriatric Physical Therapy 38 (1), 17-27. https://doi.org/10.1 519/JPT.0000000000000019

George, L.K. (1992). Economic status and subjective well-being: A review of the literature and an agenda for future research. In N.E., Cutler, D.W. Gregg, \& M.P. Lawton (Eds.), Aging, money, and life satisfaction: Aspects of financial gerontology (pp. 69-99). Springer Publishing Co.

Glezer, H. (1984). Antecedents and correlates of marriage and family attitudes in young Australian men and women. In Proceedings of the Twentieth International CFR Seminar on Social Change and Family Policies, Key Papers, Part I, Melbourne: Australian Institute of Family Studies.

Gow, A.J., Pattie, A., Whiteman, M.C., Whalley, L.J., \& Deary, I.J. (2007). Social support and successful aging. Investigating the relationships between lifetime cognitive change and life satisfaction. Journal of Individual Differences, 28, 103-115. http://dx.doi.org/10.1027/161 4-0001.28.3.103

Gray, R. S., Rukumnuaykit, P., Kittisuksathit, S., \& Thongthai, V. (2008). Inner happiness among Thai elderly. Journal of Cross-Cultural Gerontology 23, 211-224. https://doi.org/10.1007/s10823-008-90657

Grunert, K. G., Dean, M., Raats, M., Nielsen, N. A., Lumbers, M. \& The Food in Later Life Team. (2007). A measure of satisfaction with foodrelated life. Appetite 49 (2), 486-493. https://doi.org/10.1016/j.appet. 2007.03.010

Gubrium, J. F. (1973). The Myth of the Golden Years: A Socio-environmental Theory of Aging. Charles C Thomas. 
Hargreaves, M., Schlundt, D. G., \& Buchowski, M. S. (2002). Contextual factors influencing the eating behaviours of African American women: A focus group investigation. Ethnicity \& Health 7, 133-147. https: //doi.org/10.1080/1355785022000041980

Hausman, A. (2005). Hedonistic rationality: The duality of food consumption. Advances in Consumer Research 32, 404-405.

Hennessy, C. H., Moriarty, D. G., Zack, M. W., Scherr, P. A., \& Brackbill, R. B. (1994). Measuring health-related quality of life for public health surveillance. Public Health Reports 109 (5), 665-672. https://www.ncbi .nlm.nih.gov/pmc/articles/PMC1403555/

Horstmann, V., Haak, M., Tomsone, S., Iwarsson, S., \& Gräsbeck, A. (2012). Life satisfaction in older women in Latvia and Sweden? Relations to standard of living, aspects of health and coping behavior. Journal of Cross-Cultural Gerontology 27, 391-407. https://doi.org/10.1007/s1 0823-012-9176-z

Hsieh, Ch. M. (2011). Money and happiness: Does age make a difference? Ageing and Society 31 (8), 1289-1306. https://doi.org/10.1017/S014 4686X10001431

Kniazeva, K, \& Venkatesh, A. (2007). Food for thought: A study of food consumption in postmodern US culture. Journal of Consumer Behaviour 6 (6), 419-435. https://doi.org/10.1002/cb.232

Layard, R. (2005). Happiness: Lessons from a New Science. Penguin Press.

Li, H., Chi, I., \& Xu, L. (2013). Life satisfaction of older Chinese adults living in rural communities. Journal of Cross-Cultural Gerontology 28, 153-165. https://doi.org/10.1007/s10823-013-9189-2

Lobos, G., Grunert, K.G., Bustamante, M., \& Schnettler B. (2016). With health and good food, great life! Gender differences and happiness in Chilean rural older adults. Social Indicators Research 127 (2), 865-885. https://doi.org/10.1007/s11205-015-0971-0 
Lobos, Schnettler, Grunert, Lapo, Saens and Adasme-Berríos: Estimating Subjective Quality...

Lobos G., Schnettler B., Grunert K.G., \& Adasme C. (2017). The perceived resources as predictor on food satisfaction with food-related life among the Chilean elderly: An approach with generalized linear models. Journal of Nutrition, Health and Aging 21 (109), 1240-1249. https: //doi.org/10.1007/s12603-017-0901-8

Lobos, G., Schnettler, B., Lapo, C., Mera, W., \& Bustamante, M. (2019). Perceived resources and satisfaction with food-related life among Ecuadorian elderly. Journal of Nutrition Education and Behavior, 51 (6), 693-702. https://doi.org/10.1016/j.jneb.2019.01.025

Loewe, N., Bagherzadeh, M., Araya-Castillo, L., Thieme, C., \& BatistaFoguet, J.M. (2014). Life domain satisfactions as predictors of overall life satisfaction among workers: Evidence from Chile. Social Indicators Research 118, 71-86. https://doi.org/10.1007/s11205-013-0408-6

Lou, V. W. Q. (2010). Life satisfaction of older adults in Hong Kong: The role of social support from grandchildren. Social Indicators Research, 95, 377-391. https://doi.org/10.1007/s11205-009-9526-6

Lubin, B., Zuckerman, M., Breytspraak, L.M., \& Bull, N.C. (1988). Affects, demographic variables, and health. Journal of Clinical Psychology 44 (2), 131-141. http://dx.doi.org/10.1002/1097-4679(198803)44:2<131:: AID-JCLP2270440207>3.0.CO;2-F

Lyubomirsky, S., \& Lepper, H. S. (1999). A measure of subjective happiness: Preliminary reliability and construct validation. Social Indicators Research, 46 2, 137-155. https://doi.org/10.1023/A: 1006824100041

Lyubomirsky S., Sheldon, K.M., \& Schkade, D. (2005). Pursuing happiness: The architecture of sustainable change. Review of General Psychology 9 (2), 111-131. https://doi.org/10.1037/1089-2680.9.2.111

Moor, N., de Graaf, P. M., \& Komter, A. (2013). Family, welfare state generosity and the vulnerability of older adults: A cross-national study. Journal of Aging Studies 27, 347-357. https://doi.org/10.1016/j.jaging .2013 .07 .002 
Nelder, J. A., \& Wedderburn, R. W. M. (1972). Generalized linear models. Journal of the Royal Statistical Society Series A 135, 370-384. https: //doi.org/10.2307/2344614

Netuveli, G., \& Blane, D. (2008). Quality of life in older ages. British Medical Bulletin, 85 (1), 113-126. https://doi.org/10.1093/bmb/ldn003

Oishi, S., Diener, E., Lucas, R.E., \& Suh, E.M. (2009). Cross-cultural variations in predictors of life satisfaction: perspectives from needs and values. Social Indicators Research Series 38, 109-127. https://doi.org/10 .1007/978-90-481-2352-0_6

Okun, M.A., Stock, W.A., Haring, M.J., \& Witter, R.A. (1984). Health and subjective well-being: A meta-analysis. International Journal of Aging 19 (2),111-132. http://dx.doi.org/10.2190/QGJN-0N81-5957-HAQD

Pinquart, M., \& Sörensen, S. (2000). Influences of socioeconomic status, social network, and competence on subjective well-being in later life: A meta-analysis. Psychology and Aging 15 (2), 187-224. http://dx.doi.o $\mathrm{rg} / 10.1037 / 0882-7974.15 .2 .187$

Russell, R.J.H., \& Wells, P.A. (1994). Predictors of happiness in married couples. Personality and Individual Differences 17 (3), 313-321. http: //dx.doi.org/10.1016/0191-8869(94)90279-8

Schimmack, U., Schupp, J., \& Wagner, G. G. (2008). The influence of environment and personality on the affective and cognitive component of subjective well-being. Social Indicators Research 89, 41-60. http: //dx.doi.org/10.1007/s11205-007-9230-3

Schnettler B., Miranda, H., Sepúlveda, J., Denegri, M., Mora, M., \& Lobos, G. (2012). Satisfaction with life and food-related life in persons of the mapuche ethnic group in Southern Chile. A comparative analysis using logit and probit models. Journal of Happiness Studies 13, 225-246. https://doi.org/10.1007/s10902-011-9259-5

Schnettler, B., Miranda, H., Sepúlveda, J., Denegri, M., Mora, M., Lobos, G., \& Grunert, K.G. (2013). Psychometric properties of the satisfaction 
Lobos, Schnettler, Grunert, Lapo, Saens and Adasme-Berríos: Estimating Subjective Quality...

with food-related life scale: Application in Southern Chile. Journal of Nutrition, Education and Behavior 45 (5), 443-449. https://doi.org/10 .1016/j.jneb.2012.08.003

Schnettler, B., Denegri, M., Miranda, H., Sepúlveda, J., Mora, M., \& Lobos, G. (2014). Satisfaction with life and with food-related life in Central Chile. Psicothema 26 (2), 200-206. https://doi.org/10.7334/psicothe ma2013.13

Selim, S. (2008). Life satisfaction and happiness in Turkey. Social Indicators Research 88 (3), 531-562. https://doi.org/10.1007/s11205-007-9218-z

Shams, K. (2014). Determinants of subjective well-being and poverty in rural Pakistan: A micro-level study. Social Indicators Research 119 (3), 17551773. https://doi.org/10.1007/s11205-013-0571-9

Silverstein, M., Cong, Z. \& Li, S.Z. (2006). Intergenerational transfers and living arrangements of older people in rural China: consequences for psychological well-being. Journals of Gerontology: Series B 61 (5), S256S266. https://doi.org/10.1093/geronb/61.5.S256

Smith, J., Borchelt, M., \& Maier, H. (2002). Health and well-being in the young old and oldest old. Journal of Social Issues 58 (4), 715-732. http://dx.doi.org/10.1111/1540-4560.00286

Social Science Statistics. (2020). Effect size calculators for t-test. Available at https://www.socscistatistics.com/effectsize/

Sok, S.R. (2010). Factors influencing life satisfaction of Korean older adults living with family. Journal of Gerontological Nursing 36 (3), 32-40. https://doi.org/10.3928/00989134-20100202-01

Steverink, N., Westerhof, G.J., Bode, C., \& Dittmann-Kohli, F. (2001). The personal experience of aging, individual resources, and subjective wellbeing. The Journals of Gerontology: Series B Psychological Sciences and Social Sciences, 56 (6), 364-373. https://doi.org/10.1093/geronb/56.6. P364 
Theurer, K., \& Wister, A. V. (2010). Altruistic behaviour and social capitals predictors of well-being among older Canadians. Ageing and Society, 30 (1), 157-181. https://doi.org/10.1017/S0144686X09008848

Tomás, J. M., Sancho, P., Gutiérrez, M., \& Galiana, L. (2014). Predicting life satisfaction in the oldest-old: A moderator effects study. Social Indicators Research 117, 601-613. https://doi.org/10.1007/s11205-013-0357-0

Veenhoven, R. (2008). Effects of happiness on physical health and the consequences for preventive health care. Journal of Happiness Studies 9 (3), 449-469. https://doi.org/10.1007/s10902-006-9042-1

Veenhoven, R., \& Ehrhardt, J. (1995). The cross-national pattern of happiness: Test of predictions implied in three theories of happiness. Social Indicators Research 34, 33-68. https://doi.org/10.1007/BF0107 8967

Wu, J., Värnik, A., Tooding, L. M., Värnik, P., \& Kasearu, K. (2014). Suicide among older people in relation to their subjective and objective wellbeing in different European regions. European Journal of Ageing 11, 131140. https://doi.org/10.1007/s10433-013-0297-1

Xavier, F.M.F., Ferraz, M.P.T., Marc, N., Escosteguy, N.U., \& Moriguchi, E.H. (2003). Elderly people's definition of quality of life. Revista Brasileira de Psiquiatria 25 (1), 31-39. https://doi.org/10.1590/S1 516-44462003000100007

Yunong, H. (2012). Family relations and life satisfaction of older people: A comparative study between two different Hukous in China”. Ageing and Society 32 (1), 19-40. https://doi.org/10.1017/S0144686X11000067 